\title{
SOEP
}

SOEPpapers

SOEPpapers
on Multidisciplinary Panel Data Research

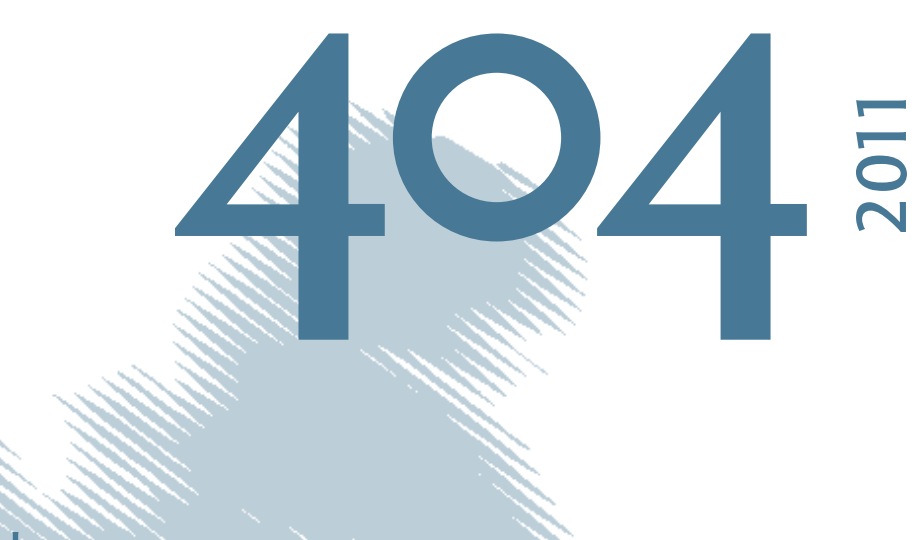

\section{Spite and cognitive skills in preschoolers}

Elisabeth Bügelmayer and C. Katharina Spieß

\section{DIW BERLIN}




\section{SOEPpapers on Multidisciplinary Panel Data Research}

at DIW Berlin

This series presents research findings based either directly on data from the German SocioEconomic Panel Study (SOEP) or using SOEP data as part of an internationally comparable data set (e.g. CNEF, ECHP, LIS, LWS, CHER/PACO). SOEP is a truly multidisciplinary household panel study covering a wide range of social and behavioral sciences: economics, sociology, psychology, survey methodology, econometrics and applied statistics, educational science, political science, public health, behavioral genetics, demography, geography, and sport science.

The decision to publish a submission in SOEPpapers is made by a board of editors chosen by the DIW Berlin to represent the wide range of disciplines covered by SOEP. There is no external referee process and papers are either accepted or rejected without revision. Papers appear in this series as works in progress and may also appear elsewhere. They often represent preliminary studies and are circulated to encourage discussion. Citation of such a paper should account for its provisional character. A revised version may be requested from the author directly.

Any opinions expressed in this series are those of the author(s) and not those of DIW Berlin. Research disseminated by DIW Berlin may include views on public policy issues, but the institute itself takes no institutional policy positions.

The SOEPpapers are available at

http://www.diw.de/soeppapers

\section{Editors:}

Joachim R. Frick (Empirical Economics)

Jürgen Schupp (Sociology, Vice Dean DIW Graduate Center)

Gert G. Wagner (Social Sciences)

Conchita D'Ambrosio (Public Economics)

Denis Gerstorf (Psychology, DIW Research Professor)

Elke Holst (Gender Studies)

Frauke Kreuter (Survey Methodology, DIW Research Professor)

Martin Kroh (Political Science and Survey Methodology)

Frieder R. Lang (Psychology, DIW Research Professor)

Henning Lohmann (Sociology, DIW Research Professor)

Jörg-Peter Schräpler (Survey Methodology, DIW Research Professor)

Thomas Siedler (Empirical Economics, DIW Graduate Center)

C. Katharina Spieß (Empirical Economics and Educational Science)

ISSN: 1864-6689 (online)

German Socio-Economic Panel Study (SOEP)

DIW Berlin

Mohrenstrasse 58

10117 Berlin, Germany

Contact: Uta Rahmann | soeppapers@diw.de 


\title{
Spite and cognitive skills in preschoolers
}

\author{
Elisabeth Bügelmayer and C. Katharina Spiess \\ DIW Berlin and FU Berlin
}

September 2011

\begin{abstract}
Although spiteful preferences play a crucial role in the development of human large-scale cooperation, there is little evidence on spiteful behavior and its determinants in children. We investigate the relationship between children's cognitive skills and spiteful behavior in a sample of 214 preschoolers aged 5-6 and their mothers. Other-regarding behavior of both mothers and children is elicited through four simple allocation decisions. A key advantage of our study is that it is carried out in a household context. Therefore, we have information about both the child's and mother's cognitive and noncognitive skills as well as health and household characteristics. We find that higher cognitive skills are associated with more spiteful behavior in children. This relationship is even more pronounced among boys and possibly reflects differences in competitiveness. Moreover, we find further gender differences depending on the measure of cognitive skills and the degree of spite. These results shed light on the determinants of the development of other-regarding preferences in humans.
\end{abstract}

Keywords: spite, other-regarding preferences, cognitive skills, child experiments, household survey studies

JEL classification: C90, C99, D03, J24 


\section{Introduction}

There is ample evidence on the importance of other-regarding behavior in human social interaction. While the presence and development of prosocial behavior is well documented (see e.g. Meier, 2007 for a survey), less research on the emergence of spiteful behavior exists. This is surprising, as spite is claimed to be an integral part of human large-scale cooperation as it induces altruistic punishment (Hauser, McAuliffe, \& Blake, 2009; Jensen, 2010). Moreover, existent research tells us little on the determinants of spite. This is even more true, if the focus is on children`s spiteful behavior. Thus, the focus of our paper is to investigate the determinants of spiteful behavior among children. We concentrate on one potential determinant, the cognitive ability of children. Cognitive skills are shown to be related to favorable economic preference parameters (Borghans, Meijers, \& Ter Weel, 2008; Burks, Carpenter, Goette, \& Rustichini, 2009; Dohmen, Falk, Huffman, \& Sunde, 2010; Frederick, 2005), but their association to other-regarding preferences is still open for investigation. However, examining this relationship promises to reveal interesting insights as cognitive skills are theoretically related to a better understanding of the consequences of social behavior (Burks et al., 2009). Furthermore, studying the relationship between other-regarding behavior and cognitive skills in young children can answer questions important to understanding the emergence of human cooperation: Do children with higher cognitive skills act more selfishly and profit maximizing? Do higher cognitive skills lead to more prosocial behavior or is it more beneficial to act spitefully?

Spiteful preferences are apparent in various studies on adult decision-making. They are related to punishment of social behavior (Falk, Fehr, \& Fischbacher, 2005) and lead to a reduction of subjects' willingness to cooperate (Fehr, Hoff, \& Kshetramade, 2008). Also, it may, theoretically, be the underlying motive of behavior in the ultimatum game (Kirchsteiger, 1994). Furthermore, spite is important because of its link to competitiveness and, thereby, 
individual economic success. Some studies point to the interrelationship between spite and competitiveness (e.g. Balafoutas, Kerschbamer, \& Sutter, 2011; Levine, 1998). Balafoutas et al. (2011) show that spiteful individuals perform significantly better than efficiency oriented or inequality averse subjects when completing a task under competitive pressure. Interestingly, when giving the choice, spiteful subjects mostly avoid direct competition. It is argued that individuals care about their relative position to others and therefore spiteful subjects might be more competitive because they want to avoid disadvantageous inequality. Also, evolutionary theories suggest that spite plays a crucial role in large-scale cooperation among humans. Jensen (2010) suggests that spite evolved as an integral part of altruistic punishment and that feeling good about another person's misfortune may be the driving force behind humans’ hyper-competitiveness. While spite has been studied in adults, little is known about envy in children and its determinants.

With respect to children, there are a number of studies examining the emergence and development of other-regarding preferences (e.g. Almas, Cappelen, Sorensen, \& Tungodden, 2010; Benenson, Pascoe, \& Radmore, 2007; Fehr, Bernhard, \& Rockenbach, 2008; Fehr, Rützler, \& Sutter, 2011; Harbaugh \& Krause, 2000), but these do not focus on spite as a negative other-related behavior. Existent studies propose that very young aged children, aged 3-4, mostly act in their own self-interest in that they keep most of the endowments that they could share. Nevertheless, most children are willing to share a small fraction of their endowments. Altruistic giving increases with age and at around 7-8 the majority of children expresses egalitarian preferences (Fehr, Bernhard, et al., 2008). Teenagers perceive inequalities that arise from variations in individual achievements as fair, and, especially for males, efficiency considerations play a significant role (Almas et al., 2010). However, these studies focus on altruistic behavior. In this study, we want to shed light on children's negative other-regarding preferences, namely spiteful preferences. These preferences can be regarded as contrary to altruism in that a spiteful person always 
experiences decreasing utility with the increase of the payoff of a reference agent. Thus, a spiteful person will incur costs to reduce the other person’s payoff (Fehr \& Schmidt, 2006).

There are only few studies focusing on children's spiteful behavior. Häger (2010) investigates envy in German school children between seven and ten years of age. In the envy treatment, children must decide between the allocations of (5:3) and (6:8) gummy bears ${ }^{1}$. Additionally, information on their socio-demographic background (siblings, sports), math grades and grades in social and working behavior are collected. The author finds that at the age of seven $20 \%$ of children choose the envious option. At the age of eight the fraction of children choosing the envious option reaches a peak at 50\% and drops thereafter. Boys opt for the envious allocation significantly more often than girls, although no information is reported on gender differences within age groups. Controlling for socio-demographic characteristics and grades, she reports that children with siblings tend to behave more enviously and children playing a team sport behave less enviously. Fehr et al. (2008a) focus on children's inequality aversion, i.e. decisions that reduce unequal distributions between themselves and their partner, with a study of 229 Swiss children between the ages of 3 and 8 . The experiment consisted of three treatments in which children had to make choices about the allocation of sweets between themselves and an anonymous partner. Results showed that 3-4 year old children mostly behaved selfishly in all games. However, by the age of 7 to 8 , the majority of children showed a clear preference for egalitarianism. The fraction of children choosing the envious allocation increased from $40 \%$ in 3-4 year olds to about $80 \%$ in older cohorts. Comparing results in the envy game by gender reveals that boys are less averse to disadvantageous inequality when the partner is an in-group member. Fehr et al. (2011) use the same design as Fehr et al. (2008a) to study other-regarding preferences and parochialism. Using 717 subjects between 8 and 17, they classify subjects into egalitarian, altruistic and spiteful types. Results show that altruism increases with age whereas egalitarianism and spitefulness strongly decline with age. The

\footnotetext{
${ }^{1}$ For instance 5 for themselves and 3 for the other child or 6 for themselves and 8 for the other child.
} 
frequency of spiteful types decreases from $42 \%$ at ages $8-9$ to $14 \%$ at ages $16-17$. However, spiteful types appear more often in the out-group than in the in-group condition. With regard to spiteful behavior, they did not find any significant gender differences. However, none of these studies focus on the particular relationship between spite and cognition.

Ex ante, it is not clear whether the association between spite and cognitive skills is positive or negative. On the one hand, children with higher cognitive skills might act strictly profit maximizing regardless of the other child's payoff. Therefore, higher cognitive skills might prevent children from acting spiteful since this would reduce their own payoff. This hypothesis is in line with the theory developed by Burks et al. (2009) on the relationship between cognitive skills and social behavior. They state that individuals with higher cognitive ability might have a better understanding of the social consequences of their behavior, especially when these are uncertain or complex. In a sequential Prisoner's Dilemma, they show that for adults cognitive ability is positively correlated with predictions about the other player's behavior as well as cooperative behavior. Along the same line, Houser and Schunk (2009) report that children between 8 and 10 tend to give more in a dictator game if they perform better in math. On the other hand, higher cognitive skills could also be positively related to spite. Certain cognitive capacities, as well as a degree of inhibitory control, are a prerequisite for spite since risks, costs and benefits of spiteful behavior must be computed (Hauser et al., 2009).

In order to study the relationship between spiteful preferences and cognition, we ran an experiment with 214 five to six year old preschoolers and their mothers in a household context. Based on the experiment by Fehr et al. (2008a), we elicit their other-regarding preferences with four simple allocation decisions (see also Bartling et al. 2009; Fehr et al. 
2011 for an application of this experiment). We extend former studies with an additional "costly envy" allocation decision. These decisions allow us to classify subjects into different preference types. This enables us to study strongly spiteful preferences where the decisionmaker has to give up own payoff in order to reduce the recipient's payoff. Furthermore, the studies cited above can only shed light on the determinants of spiteful behavior to a limited extent. As our experiment is carried out in a household context we have extensive information on parental and household characteristics as well as information on child's cognitive and noncognitive skills and health. The study by Bartling et al. (2011) uses the same dataset as we do, but it focuses on other behavioral outcomes.

We proceed as follows: In section 2 we introduce the experimental design and procedure. Section 3 presents the results, and in section 4 we conclude.

\section{Experimental Design and Procedure}

The dataset we use is part of a pilot study by the German Socio-Economic Panel (SOEP) that aims at integrating experiments into a household survey context. The SOEP is a large panel dataset, running since 1984 and is representative of the German population (Wagner, Frick, \& Schupp, 2007). The same professional survey company that carries out the SOEP implemented this pilot study. It focuses on preschool children and their mothers (see Bartling et al. 2011 for a description of the pilot study). In a first step, the population was defined to be mothers of 5 to 6 year old children, enrolled in institutional daycare in Berlin (Germany), and living in areas selected to be representative of the total population in Berlin. Once identified, information leaflets and consent forms were sent to a random sample of the population. A total of 214 mother-child dyads participated in the study ${ }^{2}$. Females were $47 \%$ of participating children. In the first step of the survey, mothers answered a detailed questionnaire covering a

\footnotetext{
${ }^{2}$ Depending on the specification, up to three observations were dropped due to missing information in the regressions.
} 
wide range of topics concerning herself, her child and the household. We have information on household characteristics, personality traits, non-cognitive skills of mothers and children, mother's cognitive skills and several indicators for the child's health. Interviews and experiments with mothers and children were carried out in their household by specially trained and experienced interviewers. In the second step of the survey, mothers and their children took part in experiments on other-regarding preferences and children's cognitive skills were measured.

To elicit children's other-regarding preferences we adapted the design of Fehr et al. (2008a) to the household context. Also, we added a fourth decision task termed "costly envy" to the original design. Participants had to make choices in four simple allocation tasks in which they distributed suns (the experimental currency) between themselves and another anonymous partner $^{3}$. To this end, children were presented with a photo of a Kindergarten group of another German town to ensure they did not know the other player (in contrast to Fehr et al. 2008a, our experiment was only carried in the outgroup condition). Children were told that at the end of the experiment they can exchange suns for gifts and the more suns they have, the more attractive their gift will be. Children did not see the gifts before the experiment. Circles with arrows either pointing to the child or to the photo of the Kindergarten group indicated how many suns the child could allocate to herself and to the other child. The child had to answer control questions to test if they understood the procedure and, if necessary, rules were explained again. Allocation choices and sides at which circles were placed were randomized among children.

We term the four allocation decisions in line with Bartling et al. (2009), who studied mother's

\footnotetext{
${ }^{3}$ See also Fehr et al. (2011) for a recent application of this design
} 
other-regarding preferences with the same experiment only differing in payoffs. In all four games, subjects had to decide between the egalitarian distribution and some alternative either making them better or worse off compared to the recipient. In the prosociality game subjects had to choose between the allocation $(1,1)$, i.e. 1 point for the decision maker, 1 for the partner, and the allocation $(1,0)$. This distribution allows the subject to endow the partner with one point without this being costly to herself. In the costly prosociality game the decision maker was faced with the choice $(1,1)$ vs. $(2,0)$. That is, increasing the partner's payoff entailed a cost to the decision maker. The envy game let the decision maker choose between the allocations $(1,1)$ and $(1,2)$. Therefore, it was possible to reduce the partner's payoff at no cost. The fourth game is a complement to previous studies using this design. We add a costly envy game in which the subject has to make a choice between $(1,1)$ and $(2,4)$. Hence, reducing the other player's payoff also results in a lower payoff for the decision maker. We believe this additional game is important as it reveals strongly envious preferences.

From behavior in single games we cannot unambiguously infer the underlying motive driving an allocation decision. Regarding the prosociality game, choosing $(1,1)$ can be due to a subject's inequality aversion (Fehr \& Schmidt, 1999) or to a preference for increasing total payoff, consistent with social welfare preferences (Charness \& Rabin, 2002). Also, a preference for increasing the payoff of the worst off player (maximin preferences) can drive this decision. Similarly, choosing $(1,1)$ in the costly prosociality game may either be an expression of a subject's inequality aversion or may reflect maximin preferences. However, a decision maker taking the $(1,1)$ option in the costly prosociality game clearly values one additional unit for their partner more than for themself. Correspondingly, the choice $(1,1)$ in the envy or the costly envy game may be either driven by an aversion to inequality or the desire to reduce the other player's payoff. Deciding for the $(1,1)$ option in the costly envy 
game clearly rules out purely selfish profit maximizing behavior as the subject is willing to forego one unit of payoff in order to decrease the recipient's payoff. To better distinguish motives driving the choices, it is necessary to jointly analyze behavior across all four games. Thus, we classify subjects into different preference types. In particular, as we focus on spiteful behavior, we classify individuals into strongly spiteful and weakly spiteful types. Strongly spiteful subjects choose in all four games the option that decreases the partner's payoff, even if it costs part of their own payoff. Subjects are classified as weakly spiteful if they reduce the other subject's payoff when it exceeds their own payoff, i.e. they choose $(1,1)$ in the envy and costly envy game. So, strongly spiteful subjects aim at minimizing the other player's payoff whenever possible, whereas weakly spiteful subjects act to reduce the other player's payoff only when they are worse off ${ }^{4}$. The classifications are summarized in Table 1.

Table 1: Allocations and classification of preference types

\begin{tabular}{|l|c|c|c|c|}
\hline & \multicolumn{2}{|c|}{ Payoff } & \multicolumn{2}{c|}{ Types } \\
\hline & Distribution A & Distribution B & $\begin{array}{c}\text { Strongly } \\
\text { spiteful }\end{array}$ & $\begin{array}{c}\text { Weakly } \\
\text { spiteful }\end{array}$ \\
\hline Prosociality & $(1,1)$ & $(1,0)$ & B & A,B \\
\hline $\begin{array}{l}\text { Costly } \\
\text { Prosociality }\end{array}$ & $(1,1)$ & $(2,0)$ & B & A,B \\
\hline Envy & $(1,1)$ & $(1,2)$ & A & A \\
\hline Costly Envy & $(1,1)$ & $(2,4)$ & A & A \\
\hline
\end{tabular}

Measures of children's cognitive skills. Before taking part in the experiment on otherregarding preferences, two dimensions of children's cognitive abilities were measured. Tests were selected and adapted to meet the requirements of the household survey context. These included easy scoring, robustness of tests to presence of family members and quick

\footnotetext{
4 Others, such as Bartling et al (2009), define this allocation as behindness averse, as one type of inequality aversion. However, our evidence from the multivariate regressions (see below) speaks in favour of spite driving the choices and not inequality aversion. If it were inequality aversion, we should also find a significant relationship between aheadness aversion and cognitive skills. Further estimates have shown that this is not the case: There is only a significant relation between behindness averse respectively weakly spiteful and cognition, but not between the other type of inequality aversion, namely aheadness aversion and cognition (results are available from the authors upon request).
} 
familiarization of children to the tasks they had to perform (Weinert et al., 2007). The tests serve as indicators for a child's crystalline and fluid intelligence, but cannot be used to calculate IQ scores.

To measure crystalline intelligence and verbal skills, an adaptation of the Peabody Picture Vocabulary Test Revised (PPVT-R) (Dunn \& Dunn, 2007) was employed. We used a shortened version of this widely used test. It is untimed and assesses the receptive vocabulary of individuals and is therefore influenced by culture and education. The interviewer shows the child four pictures and reads a word describing one of these pictures. The child has to select the picture that fits to the word. In total, our shortened version consists of 61 items. On average, 46 items were correctly specified, which corresponds to $75 \%$. A nonparametric Mann-Whitney test showed that there is no statistically significant gender difference in scores $(p=0.25)$. Figure 1 shows the distribution of correct answers in the PPVT-R, which looks close to normal but we reject the null hypothesis of normality (Shapiro-Wilk test, $\mathrm{p}<0.001$ ).

\section{Figure 1: Distribution of PPVT-R}

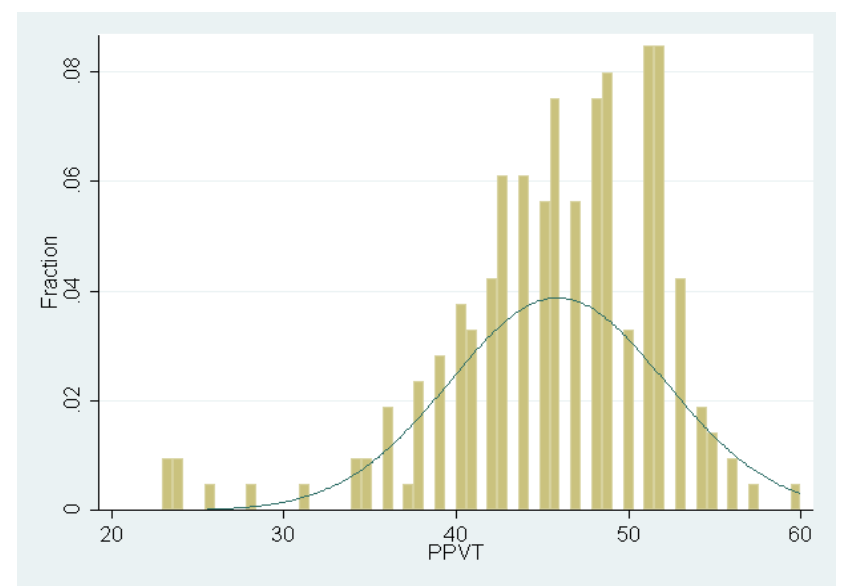

Source: SOEP Berlin Pilot Study, own calculations.

Additionally, children's nonverbal reasoning competences were assessed as an indicator for 
fluid intelligence. To this end, we used a subtest of the Culture Fair Intelligence Test (CFT1) (Weiß \& Osterland, 1997). The subtest “Matrices” is designed to minimize cultural influences and measure general cognitive ability, independent from language skills (Weiß \& Osterland, 1997). The interviewer shows the child a matrix with three abstract symbols where a blank box indicates that one is missing. The child has to pick the missing symbol from five presented alternatives. This task consists of 12 items and captures identification of relationships and analogies. On average, children correctly matched 6.6 items. ${ }^{5}$ Table 2 presents the distribution of correct answers in the subtest of the CFT1. We cannot reject the null hypothesis of normal distribution (Shapiro-Wilk test, $\mathrm{p}=0.82$ ). This supports our measures as psychological research on cognitive abilities commonly finds that these are distributed normally in a population.

\section{Figure 2: Distribution of CFT1 - subtest “Matrices”}

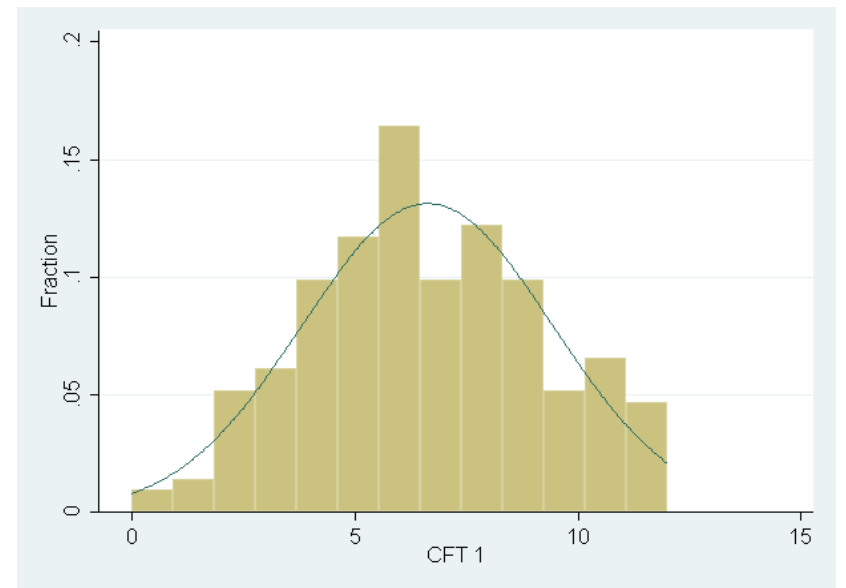

Source: SOEP Berlin Pilot Study, own calculations.

As in the PPVT-R, no statistically significant gender differences are found (Mann-Whitney test, $\mathrm{p}=0.44$ ). Correlation between the two tests is 0.36 (Spearman, $\mathrm{p}<0.001$ ). This suggests that the two measures are closely related but capture different dimensions of cognitive ability (Dohmen et al. 2010).

\footnotetext{
${ }^{5}$ This is slightly more than 5.9, which is the average Weiß and Osterland (1997) observe in their revised German version of the CFT1.
} 
Other determinants and control variables. In addition to cognitive skills, we also include children's Big Five personality traits in our regressions, since it is likely that a child's personality and their preference for spite are related. Furthermore, Borghans et al. (2008) show that an individual's personality affects performance in tests on cognitive ability. In particular, conscientiousness, emotional stability and extraversion are related to scores in cognitive tests. Thus, by including children's personality traits, we control for the influence of personality on test taking behavior. We use mother's ratings of their children in a short version of the five-factor questionnaire (Weinert et al. 2007). Mothers answer ten items on an eleven point Likert-scale on their child's personality, which are subsequently classified into the five dimensions: Openness to experience, Conscientiousness, Extraversion, Agreeableness and Neuroticism.

Further, we add controls for children's social behavior that can possibly be related to spiteful decisions in the experiment. To this end, we include mother's ratings in the subscales "Peer relationship problems" and "Prosocial behavior" of the Strengths and Difficulties Questionnaire (SDQ). This is a standardized questionnaire (Goodman, 1997) designed to assess a child's problem behavior in five dimensions. The analysis also includes a proxy for empathy. We use mother's rating of her child from a question on how well her child can put themself in someone else's shoes as a proxy for empathy. Empathy is shown to be associated with prosocial and altruistic behavior (Andreoni \& Rao, 2011) and thus might reduce spiteful behavior in the allocation games.

Further, we include measures for mothers' other-regarding preferences as explanatory variables. Mother's behavior was measured in similar allocation tasks. Mothers must make decisions in a prosociality, costly proscociality, envy and costly envy game (for a more detailed description of this design see Bartling et al., 2009). After answering the 
questionnaire, mothers participated in games similar as to those that their children played. However, games were adjusted to adults, that is, payoffs were increased and paid in Euro. Moreover, decisions were taken on a computer unobserved by the interviewer and one of the decisions was later randomly selected and paid to the subjects. Also, a dummy variable indicating if another person was present during the tests and games with the child was included in the regressions. As an important predictor of child health, we control for birth weight (see, e.g. Currie 2011). Apart from this, we control for other socio-economic variables such as gender, number of siblings, birth order and household income.

\section{Results}

First, we present descriptive statistics of decisions in single games and preference types and their relation to children's cognitive skills. Then, we will proceed by further exploring this relationship controlling for the impact of other child and family characteristics.

\subsection{Descriptive statistics of behavior in single games and preference types}

The percentages of children selecting the egalitarian option in the four decision tasks are presented in Table 2.

Table 2: Percentage of children selecting the egalitarian option

\begin{tabular}{|c|c|}
\hline Game & Percentage of children choosing (1,1) \\
\hline $\begin{array}{c}\text { Prosociality } \\
(1,1) \text { vs. (1,0) }\end{array}$ & $45 \%$ \\
\hline $\begin{array}{c}\text { Costly Prosociality } \\
(1,1) \text { vs. }(2,0)\end{array}$ & $20 \%$ \\
\hline $\begin{array}{c}\text { Envy } \\
(1,1) \text { vs. }(1,2)\end{array}$ & $54 \%$ \\
\hline $\begin{array}{c}\text { Costly Envy } \\
(1,1) \text { vs. }(2,4)\end{array}$ & $27 \%$ \\
\hline
\end{tabular}

Source: SOEP Berlin Pilot Study, own calculations.

The table shows that that about half of the children (55\%) are not willing to increase their partner's payoff even if it is not costly. However, the frequency of $(1,1)$ choices in the 
prosociality game does not differ significantly from $50 \%$ (binomial test, $\mathrm{p}=0.19$ ). This result is nearly identical with the results of Fehr et al. (2008a). ${ }^{6}$ As about half of the children were willing to increase the other child's payoff in the prosociality game, it is not surprising that the fraction of children who were willing to share when this was costly dropped to $20 \%$ in the costly prosociality game. This fraction again corresponds to the finding of Fehr et al. (2008a) in the outgroup decision and rejects the null hypotheses of random choices (binomial test, $\mathrm{p}<0.001$ ). Slightly more than $50 \%$ of children chose to decrease their partner's payoff when this did not incur any losses to them. But this fraction does not differ significantly from $50 \%$ (binomial test, $\mathrm{p}=0.25)$. Moreover, this percentage of children choosing the $(1,1)$ option in the envy treatment is consistent with the results of Fehr et al. (2008a) in the ingroup but not in the outgroup condition. As noted, we complement previous studies by adding a costly envy game. In this game, a majority of children maximized own/partner's/or joint payoff. Nevertheless, a non-negligible fraction of $27 \%$ was willing to reduce the other subject's payoff, even when this cost their own payoff. We reject the null hypotheses of random choices (binomial test, $\mathrm{p}<0.001)$

In terms of gender, we do not observe any differences between boys and girls in the prosociality, costly prosociality or costly envy game (Chi2 tests, $p=0.44, p=0.43, p=0.24$; respectively). However, boys choose the $(1,1)$ option significantly more often than girls in the envy game (Chi2 test, $\mathrm{p}=0.04)$.

Next, we look at the choice pattern in all four games to better identify spiteful behavior. Around $23 \%$ of subjects are classified as weakly spiteful, that is, they reduced their partner's payoff in the envy and costly envy decision when the partner was better off. Of all subjects, $15 \%$ were strongly spiteful in terms of minimizing their partner's payoff in all four games.

\footnotetext{
${ }^{6}$ To our knowledge this is the only directly comparable study in terms of age of children and games. Specifically, we compare our results with the "outgroup" treatment in their analysis, as like in our study children did not know their partners in the outgroup treatment.
} 
There is no statistically significant difference between boys and girls in terms of strongly spiteful preferences and weakly spiteful preferences. Häger (2010) and Fehr et al. (2008a) found that about $20 \%$ of children displayed spiteful preferences, although their results are not directly comparable as either children were older or faced different decisions compared to this study.

If we analyze the relationship between spiteful behavior and cognitive skills first with nonparametric tests, we get a statistically significant relationship between a child's measure of fluid intelligence and the decision to choose the envious option in the envy and costly envy game (Mann-Whitney test; $\mathrm{p}=0.008, \mathrm{p}<0.001$, respectively). Mann-Whitney tests also suggest that there is a statistically significant difference between the underlying distributions of correct answers in the test of fluid intelligence for children who were classified as strongly spiteful or weakly spiteful and those who were not $(\mathrm{p}<0.001, \mathrm{p}<0.001)$.In contrast, the association between a child's ability of verbal reception and its spiteful preferences does not seem to be as pronounced. Only between weakly spiteful preferences and the scores of the PPVT is there a statistically significant relationship (Mann-Whitney test, $\mathrm{p}=0.05$ ).

\subsection{Regression results}

We proceed by presenting results from Probit regressions investigating the association between children's spiteful preferences and cognitive skills, while controlling for the influence of other children and family specific characteristics. First, results for single games are presented, and then results for preference types are depicted. Results are shown for the whole sample and separately for boys and girls. Also, we estimate two separate models including either the children's personality or the mother's behavior in the experiment on other-regarding preferences. 
Behavior in single games: Envy and Costly envy decision. Table 3 shows that cognitive abilities are important determinants of behavior in the envy game for girls but not for boys. Having a fluid intelligence above the $75 \%$ percentile significantly increases the probability to choose the envious option for girls. However, girls' crystalline intelligence is negatively related to choosing $(1,1)$ in the envy game. In contrast, boys' decisions are more strongly affected by other factors such as birth weight and mother's prosocial behavior.

When looking at the costly envy decision, fluid cognitive ability is also positively related to behaving enviously (Table 4). However, it is boys with cognitive abilities above the median who have a significantly higher propensity to reduce the other player's payoff even if it is costly. Again, scoring above the median in the vocabulary test decreases the probability of choosing the costly envy option, but only for girls.

Gender differences also prevail in the effects of the other covariates. Regarding personality and non-cognitive skills. Conscientiousness significantly decreases the propensity to minimize the other subject's payoff for boys, while empathy has the opposite effect. For girls, having problems with peers and their mother's prosocial behavior are positively related to costly envy behavior.

Behavior across all games: Weakly spiteful and strongly spiteful types. Analyzing decisions across all four games and classifying subjects into preference types helps to better distinguish spiteful behavior from other motives. Overall, regressions confirm the positive relationship between cognitive skills and spiteful behavior observed in single games.

First we present results from children classified as weakly spiteful. These children reduced the other player's payoff only when it was larger than their own. In particular, the propensity of being a weakly spiteful type is, ceteris paribus, increased by $20 \%-30 \%$ for boys with cognitive skills above the median, as measured by CFT1. Also, boys’ vocabulary skills are 
positively correlated with being weakly spiteful. In contrast, girls scoring above the median in the crystalline intelligence test are less likely to be classified as weakly spiteful.

Regarding personality traits, boys who are more open to experience tend to be less likely to be weakly spiteful. Again, as in single games, being able to put oneself in the position of other people is positively associated to envious behavior across all games for boys but not for girls.Of mother's other-regarding preferences, only her prosociality is related to children's behavior.

Next, we present determinants of strongly spiteful preferences, that is, behavior that minimizes the other subject's gains in every game. Again, results differ according to gender. Whereas in boys fluid cognitive abilities above the median increase the probability of being classified as strongly spiteful by up to $26 \%$, girls' cognitive skills are not related to strongly spiteful behavior. Similar to results of weakly spiteful types, openness to experience is associated with less spiteful behavior in boys. However, the more empathic boys are, the more spitefully they act.

\subsection{Summary of results}

In sum, regressions reveal that cognitive skills influence spiteful behavior in single games as well as over all four distribution decisions. After examining this relationship first in a sample of all children and then separately by gender, two main results become apparent.

Firstly, higher fluid cognitive ability is related to an increased propensity to act spitefully in children. This applies to decisions in the envy and costly envy game as well as to the classification into strongly spiteful and weakly spiteful types. For example, fluid cognitive ability above the median increases, ceteris paribus, the probability of deciding spitefully in single games as well as overall games between $16 \%$ and $20 \%$ in children. 
Secondly, there are marked gender differences in the association between cognitive skills and spite. The previous result is mainly driven by the boys' subsample, as fluid cognitive ability is a highly significant predictor for choosing the spiteful allocations for boys but not for girls. However, while scores in the verbal reception test are not related to boys' behavior they significantly decrease the propensity to reduce the other player's payoff in girls. In addition to cognitive skills, a child's problems with peers, empathy and mother's prosociality are also significantly associated with increased spiteful behavior across all the models. Boys who are able to put themselves into another person's shoes are more likely to reduce the other subject's payoff. This contradicts the finding of Andreoni and Rao (2011), who find a positive association between empathy and altruistic giving in adults. The discrepancy in results might be explained by the fundamental developments of preferences during childhood and adolescence or in the different measures for empathy. Surprisingly, having a mother who increased the other subject's payoff in the prosocial game also increased the probability of spiteful behavior in the child. Thus, at this early age, our results do not indicate a positive intergenerational transmission of spite.

\section{Discussion and Conclusion}

In this study, we use data from a pilot study that integrates experiments into a household survey in order to analyze children's spitefulness and its determinants. On the one hand, spite is shown to be the underlying motive for punishment of social behavior (Falk et al. 2005) and, on the other hand it is argued that it is crucial for large-scale human cooperation (Jensen, 2010) and competitiveness (Balafoutas et al., 2011). We especially focus on cognitive ability as a predictor for spiteful behavior. Although previous literature studies the relationship between cognitive skills and economic preference parameters, such as risk aversion and patience (Borghans et al., 2008; Dohmen et al., 2010; Frederick, 2005), there is little evidence on the relationship between cognitive skills and other-regarding preferences. Children's other- 
regarding preferences are measured through four simple allocation decisions that allow the analysis of decisions both in single games as well as through choice patterns across all games.

Overall, results in single games and across preference types show that cognitive skills are important determinants of children's spiteful behavior. This finding is robust, controlling for children's personality and non-cognitive skills as well as maternal and household characteristics. Two main conclusions can be drawn from our analysis. First, children more endowed with fluid cognitive ability are significantly more likely to display spiteful behavior. This shows that children with higher cognitive skills do not act strictly payoff maximizing because the decision maker had to forego own payoff in order to reduce the recipient's payoff. Instead, children with higher cognitive skills cared very much about their position relative to others. They not only had an increased propensity of decreasing the other subject's payoff in single games but also of minimizing the payoff in all four games whenever possible or when the recipient was better off. This positive association is consistent with evolutionary theories suggesting that certain cognitive capacities and inhibitory control are necessary in order for spiteful acts to occur (Hauser et al., 2009). Costs and benefits of spite must be calculated and consequences must be taken into account. Moreover, to forego one’s own payoff in order to reduce another person's payoff demands self-control. Self-control is shown to be positively related to cognitive abilities; one example is the association between patience and cognitive skills (e.g. Frederick 2005.

The second main finding of our study is that boys drive the relationship between spite and fluid cognitive skills. This becomes especially apparent when analyzing the probability of being of the strongly spiteful type. Boys with higher cognitive skills in all four games choose the distribution that makes them as well off as possible compared to other children. Looking at the choice pattern of the strongly spiteful type from this perspective, it could also be 
attributed to competitive preferences in the sense of Charness and Rabin (2002) ${ }^{7}$. Then, it might be possible that gender differences in spite that we observe, in effect, reflect gender differences in competitiveness. There is experimental evidence that these gender differences exist among children (see, e.g. Sutter \& Rützler, 2010 and Gneezy \& Rustichini, 2004). The interrelationship between spite and competitiveness is noted (Levine 1998), but it was only Balafoutas et al. (2011) who examine the direct link. Taking this literature into account, our result might partly be interpreted as increased competitiveness among boys with higher cognitive skills.

Moreover, if our results, which are based on a sample of preschoolers, could be predictors for adult behavior, they might contribute further to the explanation of inequalities in economic success. Those inequalities that are attributed to differences in cognitive abilities might be reinforced by behavior related to these skills (Dohmen et al., 2010). Our results might be an indication that the success of individuals with higher cognitive skills is also driven by associated spiteful behavior. However, our findings relate to preschoolers and prediction of adult behavior is hardly possible as preferences change greatly with age. Thus, more research regarding the interrelationships between cognitive skills and other-regarding preferences over the life cycle is certainly needed.

Moreover, future research might expand the research design of our study and help validate our results. First, it must be noted that games in our experiment were one-shot. It is subject to further investigation if a strategic setting would induce different results. Would this lead to an increase in cooperation among children with higher cognitive skills, as they might then perceive prosocial behavior as an investment? But even if this were the case, it remains unexplained why children, who are likely to better understand the consequences of their

\footnotetext{
7 "Player B always prefers to do as well as possible in comparison to A...” (Charness and Rabin 2002, p. 823).
} 
actions (i.e. in our case that there will be no consequences), are willing to give up own payoff to harm another anonymous child. Second, our results on gender differences are drawn on relatively small samples, further studies must show if they are robust. Third, further studies using other measures of cognitive skills, are needed to see how sensitive the results are with respect to the measures used. In any case further research is needed to precisely pin down the mechanisms behind our results. 


\section{References}

Almas, I., Cappelen, A. W., Sorensen, E. O., \& Tungodden, B. (2010). Fairness and the Development of Inequality Acceptance. Science, 328(5982), 1176-1178. AMER ASSOC ADVANCEMENT SCIENCE. doi:10.1126/science.1187300

Andreoni, J., \& Rao, J. M. (2011). The power of asking: How communication affects selfishness, empathy, and altruism. Journal of Public Economics, 95(7-8), 513-520. doi:10.1016/j.jpubeco.2010.12.008

Balafoutas, L., Kerschbamer, R., \& Sutter, M. (2011). Distributional Preferences and Competitive Behavior. forthcoming in: Journal of Economic Behavior and Organization.

Bartling, B., Fehr, E., \& Schunk, D. (2011). Health and Competitiveness in Children: An Experimental Analysis. forthcoming in: Experimental Economics.

Bartling, B., Fehr, E., Maréchal, M. A., \& Schunk, D. (2009). Egalitarianism and Competitiveness. American Economic Review, 99(2), 93-98. AMER ECONOMIC ASSOC. doi:10.1257/aer.99.2.93

Benenson, J., Pascoe, J., \& Radmore, N. (2007). Children's altruistic behavior in the dictator game. Evolution and Human Behavior, 28(3), 168-175.

doi:10.1016/j.evolhumbehav.2006.10.003

Borghans, L., Meijers, H., \& Ter Weel, B. (2008). The Role of Noncognitive Skills in Explaining Cognitive Test Scores. Economic Inquiry, 46(1), 2-12. doi:10.1111/j.14657295.2007.00073.x

Burks, S. V., Carpenter, J. P., Goette, L., \& Rustichini, A. (2009). Cognitive skills affect economic preferences, strategic behavior, and job attachment. Proceedings of the National Academy of Sciences of the United States of America, 106(19), 7745-50. doi:10.1073/pnas.0812360106

Charness, G., \& Rabin, M. (2002). Understanding Social Preferences with Simple Tests. The Quarterly Journal of Economics, 117(3), 817-869. MIT Press 238 Main St., Suite 500, Cambridge, MA 02142-1046 USA journals-info@mit.edu. doi:10.1162/003355302760193904

Dohmen, T., Falk, A., Huffman, D., \& Sunde, U. (2010). Are Risk Aversion and Impatience Related to Cognitive Ability? American Economic Review, 100(3), 1238-1260. AMER ECONOMIC ASSOC. doi:10.1257/aer.100.3.1238

Falk, A., Fehr, E., \& Fischbacher, U. (2005). Driving Forces Behind Informal Sanctions. Econometrica, 73(6), 2017-2030. doi:10.1111/j.1468-0262.2005.00644.x

Fehr, E., \& Schmidt, K. M. (1999). A Theory Of Fairness, Competition, and Cooperation*. Quarterly Journal of Economics, 114(3), 817-868. MIT Press 238 Main St., Suite 500, Cambridge, MA 02142-1046 USA journals-info@mit.edu. 
Fehr, E., \& Schmidt, K. M. (2006). Chapter 8 The Economics of Fairness, Reciprocity and Altruism - Experimental Evidence and New Theories. In R. and A. Serge-Christophe Kolm and Jean Mercier Ythier BT - Handbook on the Economics of Giving (Ed.), Foundations (Vol. 1, pp. 615-691). Elsevier.

Fehr, E., Bernhard, H., \& Rockenbach, B. (2008). Egalitarianism in young children. Nature, 454(7208), 1079-83. NATURE PUBLISHING GROUP. doi:10.1038/nature07155

Fehr, E., Hoff, K., \& Kshetramade, M. (2008). Spite and Development. American Economic Review, 98(2), 494-499. AMER ECONOMIC ASSOC. doi:10.1257/aer.98.2.494

Fehr, E., Rützler, D., \& Sutter, M. (2011). The Development of Egalitarianism, Altruism, Spite and Parochialism in Childhood and Adolescence. IZA Discussion Paper, (5530).

Frederick, S. (2005). Cognitive Reflection and Decision Making. The Journal of Economic Perspectives, 19(4), 25-42. American Economic Association.

Gneezy, U., \& Rustichini, A. (2004). Gender and Competition at a Young Age. American Economic Review, 94(2), 377-381. American Economic Association.

Goodman, R. (1997). The Strengths and Difficulties Questionnaire: A Research Note. Journal of Child Psychology and Psychiatry, 38(5), 581-586. doi:10.1111/j.14697610.1997.tb01545.x

Harbaugh, W. T., \& Krause, K. (2000). Children's altruism in public good and dictator experiments. ECONOMIC INQUIRY, 38(1), 95-109. WESTERN ECONOMIC ASSOC INT.

Hauser, M., McAuliffe, K., \& Blake, P. R. (2009). Evolving the ingredients for reciprocity and spite. Philosophical transactions of the Royal Society of London. Series B, Biological sciences, 364(1533), 3255-66. doi:10.1098/rstb.2009.0116

Häger, K. (2010). Envy and Altruism in Children.

Jensen, K. (2010). Punishment and spite, the dark side of cooperation. Philosophical transactions of the Royal Society of London. Series B, Biological sciences, 365(1553), 2635-50. doi:10.1098/rstb.2010.0146

Kirchsteiger, G. (1994). The role of envy in ultimatum games. Journal of Economic Behavior \& Organization, 25(3), 373-389. doi:10.1016/0167-2681(94)90106-6

Levine, D. K. (1998). Modeling Altruism and Spitefulness in Experiment. Review of Economic Dynamics, 1(3), 593 - 622.

Meier, S. (2007). A Survey of Economic Theories and Field Evidence on Pro-Social Behavior. In B. S. Frey \& A. Stutzer (Eds.), Economics and Psychology: A Promising New Cross-Disciplinary Field. The MIT Press.

Wagner, G. G., Frick, J. R., \& Schupp, J. (2007). The German Socio-Economic Panel Study (SOEP) - Scope, Evaluation and Enhancements. Schmollers Jahrbuch - Journal of Applied Social Science Studies, 127(1), 139-169. 
Weinert, S., Asendorpf, J. B., Beelmann, A., Doil, H., Frevert, S., \& Lohaus, A. (2007). Expertise zur Erfassung von psychologischen Personmerkmalen bei Kindern im Alter von fünf Jahren im Rahmen des SOEP. DIW Data Documentation, 20.

Weiß, R. H., \& Osterland, J. (1997). CFT 1 - Grundintelligenztest Skala 1. Göttingen: Hogrefe. 
Table 3: Regression results on behavior in single games: Envy decision

\begin{tabular}{|c|c|c|c|c|c|c|}
\hline & Full Sample & $\begin{array}{c}\text { Female } \\
(1)\end{array}$ & Male & Full Sample & $\begin{array}{c}\text { Female } \\
(2)\end{array}$ & Male \\
\hline Female & $\begin{array}{c}-0.163^{* *} \\
{[0.076]}\end{array}$ & & & $\begin{array}{c}-0.166^{* *} \\
{[0.073]}\end{array}$ & & \\
\hline CFT1>50\% perc. & $\begin{array}{c}0.048 \\
{[0.085]}\end{array}$ & $\begin{array}{c}0.019 \\
{[0.160]}\end{array}$ & $\begin{array}{c}0.121 \\
{[0.123]}\end{array}$ & $\begin{array}{c}0.028 \\
{[0.085]}\end{array}$ & $\begin{array}{c}0.073 \\
{[0.153]}\end{array}$ & $\begin{array}{c}0.084 \\
{[0.117]}\end{array}$ \\
\hline CFT1>75\% perc. & $\begin{array}{c}0.192 * \\
{[0.106]}\end{array}$ & $\begin{array}{c}0.373 * * \\
{[0.165]}\end{array}$ & $\begin{array}{c}-0.010 \\
{[0.175]}\end{array}$ & $\begin{array}{c}0.211 * * \\
{[0.101]}\end{array}$ & $\begin{array}{c}0.340 * * \\
{[0.153]}\end{array}$ & $\begin{array}{c}-0.028 \\
{[0.175]}\end{array}$ \\
\hline PPVT $>50 \%$ perc. & $\begin{array}{c}-0.079 \\
{[0.090]}\end{array}$ & $\begin{array}{c}-0.397 * * * \\
{[0.144]}\end{array}$ & $\begin{array}{c}0.185 \\
{[0.127]}\end{array}$ & $\begin{array}{c}-0.082 \\
{[0.089]}\end{array}$ & $\begin{array}{c}-0.347 * * * \\
{[0.130]}\end{array}$ & $\begin{array}{c}0.149 \\
{[0.126]}\end{array}$ \\
\hline PPVT>75\% perc. & $\begin{array}{c}0.074 \\
{[0.113]}\end{array}$ & $\begin{array}{c}0.189 \\
{[0.195]}\end{array}$ & $\begin{array}{c}-0.079 \\
{[0.167]}\end{array}$ & $\begin{array}{c}0.044 \\
{[0.113]}\end{array}$ & $\begin{array}{c}0.150 \\
{[0.184]}\end{array}$ & $\begin{array}{c}-0.077 \\
{[0.167]}\end{array}$ \\
\hline Number of siblings & $\begin{array}{c}0.028 \\
{[0.057]}\end{array}$ & $\begin{array}{c}-0.122 \\
{[0.112]}\end{array}$ & $\begin{array}{c}0.129 * \\
{[0.074]}\end{array}$ & $\begin{array}{c}0.029 \\
{[0.055]}\end{array}$ & $\begin{array}{c}-0.069 \\
{[0.099]}\end{array}$ & $\begin{array}{c}0.079 \\
{[0.074]}\end{array}$ \\
\hline Birth order & $\begin{array}{c}0.015 \\
{[0.065]}\end{array}$ & $\begin{array}{c}0.126 \\
{[0.134]}\end{array}$ & $\begin{array}{c}-0.008 \\
{[0.088]}\end{array}$ & $\begin{array}{c}0.012 \\
{[0.065]}\end{array}$ & $\begin{array}{c}0.028 \\
{[0.122]}\end{array}$ & $\begin{array}{c}0.046 \\
{[0.092]}\end{array}$ \\
\hline Log of birth weight & $\begin{array}{c}0.140 \\
{[0.211]}\end{array}$ & $\begin{array}{c}-0.308 \\
{[0.365]}\end{array}$ & $\begin{array}{c}0.718 * * \\
{[0.317]}\end{array}$ & $\begin{array}{c}0.118 \\
{[0.209]}\end{array}$ & $\begin{array}{c}-0.156 \\
{[0.353]}\end{array}$ & $\begin{array}{l}0.507 * \\
{[0.290]}\end{array}$ \\
\hline Extraversion & $\begin{array}{c}0.012 \\
{[0.048]}\end{array}$ & $\begin{array}{c}0.006 \\
{[0.085]}\end{array}$ & $\begin{array}{c}0.010 \\
{[0.067]}\end{array}$ & & & \\
\hline Conscientiousness & $\begin{array}{c}0.036 \\
{[0.041]}\end{array}$ & $\begin{array}{c}0.015 \\
{[0.074]}\end{array}$ & $\begin{array}{c}0.001 \\
{[0.055]}\end{array}$ & & & \\
\hline Agreeableness & $\begin{array}{c}0.006 \\
{[0.045]}\end{array}$ & $\begin{array}{c}0.032 \\
{[0.076]}\end{array}$ & $\begin{array}{c}0.025 \\
{[0.062]}\end{array}$ & & & \\
\hline Openness & $\begin{array}{c}-0.045 \\
{[0.043]}\end{array}$ & $\begin{array}{c}0.078 \\
{[0.083]}\end{array}$ & $\begin{array}{l}-0.128 * \\
{[0.067]}\end{array}$ & & & \\
\hline Neuroticism & $\begin{array}{c}-0.026 \\
{[0.045]}\end{array}$ & $\begin{array}{c}-0.023 \\
{[0.066]}\end{array}$ & $\begin{array}{c}-0.035 \\
{[0.068]}\end{array}$ & & & \\
\hline
\end{tabular}


Table 3: ... continued

\begin{tabular}{|c|c|c|c|c|c|c|}
\hline Problems with peers & $\begin{array}{c}0.077^{*} \\
{[0.043]}\end{array}$ & $\begin{array}{c}0.134 \\
{[0.092]}\end{array}$ & $\begin{array}{c}0.103 * \\
{[0.055]}\end{array}$ & & & \\
\hline Prosocial behavior & $\begin{array}{c}0.005 \\
{[0.047]}\end{array}$ & $\begin{array}{c}-0.064 \\
{[0.084]}\end{array}$ & $\begin{array}{c}0.048 \\
{[0.068]}\end{array}$ & & & \\
\hline Empathy & $\begin{array}{c}0.102 \\
{[0.066]}\end{array}$ & $\begin{array}{l}0.226^{*} \\
{[0.116]}\end{array}$ & $\begin{array}{c}0.093 \\
{[0.093]}\end{array}$ & & & \\
\hline Prosociality mother & & & & $\begin{array}{c}0.387 * * * \\
{[0.103]}\end{array}$ & $\begin{array}{l}0.297 * \\
{[0.155]}\end{array}$ & $\begin{array}{c}0.574 * * * \\
{[0.131]}\end{array}$ \\
\hline Costly prosociality mother & & & & $\begin{array}{c}0.031 \\
{[0.111]}\end{array}$ & $\begin{array}{c}0.060 \\
{[0.158]}\end{array}$ & $\begin{array}{c}-0.105 \\
{[0.165]}\end{array}$ \\
\hline Envy mother & & & & $\begin{array}{c}0.048 \\
{[0.137]}\end{array}$ & $\begin{array}{c}0.171 \\
{[0.199]}\end{array}$ & $\begin{array}{c}-0.058 \\
{[0.192]}\end{array}$ \\
\hline Costly envy mother & & & & $\begin{array}{c}-0.026 \\
{[0.118]}\end{array}$ & $\begin{array}{c}-0.119 \\
{[0.187]}\end{array}$ & $\begin{array}{c}0.070 \\
{[0.180]}\end{array}$ \\
\hline Other person present & $\begin{array}{c}0.005 \\
{[0.078]}\end{array}$ & $\begin{array}{c}-0.155 \\
{[0.124]}\end{array}$ & $\begin{array}{c}0.135 \\
{[0.107]}\end{array}$ & $\begin{array}{c}0.057 \\
{[0.080]}\end{array}$ & $\begin{array}{l}-0.068 \\
{[0.126]}\end{array}$ & $\begin{array}{c}0.177 \\
{[0.112]}\end{array}$ \\
\hline $\begin{array}{l}\text { Observations } \\
\text { Pseudo } R^{2}\end{array}$ & $\begin{array}{c}212 \\
0.085\end{array}$ & $\begin{array}{c}100 \\
0.184\end{array}$ & $\begin{array}{c}112 \\
0.174\end{array}$ & $\begin{array}{c}213 \\
0.097\end{array}$ & $\begin{array}{c}100 \\
0.155\end{array}$ & $\begin{array}{c}113 \\
0.164\end{array}$ \\
\hline
\end{tabular}

Notes: The table reports the marginal effects of probit models (standard errors in parentheses). The dependent variable is a dummy variable indicating whether the child has chosen the envy option. Significance levels are denoted as follows: ${ }^{*} \mathrm{p}<0.1,{ }^{* *} \mathrm{p}<0.05,{ }^{* * *} \mathrm{p}<0.01$. Additional controls: age in months, age in months squared, mother's vocational training (dummy), mother college degree (dummy), Log of monthly household income. Source: SOEP Berlin Pilot Study, own calculations. 
Table 4: Regression results on behavior in single games: Costly envy decision

\begin{tabular}{|c|c|c|c|c|c|c|}
\hline & Full Sample & $\begin{array}{c}\text { Female } \\
\text { (1) }\end{array}$ & Male & Full Sample & $\begin{array}{c}\text { Female } \\
\text { (2) }\end{array}$ & Male \\
\hline Female & $\begin{array}{c}-0.117 * \\
{[0.063]}\end{array}$ & & & $\begin{array}{c}-0.121 * \\
{[0.063]}\end{array}$ & & \\
\hline CFT1 $>50 \%$ perc. & $\begin{array}{c}0.212 * * * \\
{[0.071]}\end{array}$ & $\begin{array}{c}0.100 \\
{[0.098]}\end{array}$ & $\begin{array}{c}0.291^{* * *} \\
{[0.109]}\end{array}$ & $\begin{array}{c}0.167 * * \\
{[0.072]}\end{array}$ & $\begin{array}{c}0.049 \\
{[0.101]}\end{array}$ & $\begin{array}{c}0.204 * * \\
{[0.104]}\end{array}$ \\
\hline CFT1 $>75 \%$ perc. & $\begin{array}{c}0.034 \\
{[0.093]}\end{array}$ & $\begin{array}{c}0.106 \\
{[0.153]}\end{array}$ & $\begin{array}{c}0.116 \\
{[0.162]}\end{array}$ & $\begin{array}{c}0.060 \\
{[0.096]}\end{array}$ & $\begin{array}{c}0.122 \\
{[0.142]}\end{array}$ & $\begin{array}{c}0.067 \\
{[0.153]}\end{array}$ \\
\hline PPVT $>50 \%$ perc. & $\begin{array}{c}-0.099 \\
{[0.075]}\end{array}$ & $\begin{array}{c}-0.238 * * \\
{[0.097]}\end{array}$ & $\begin{array}{c}0.061 \\
{[0.121]}\end{array}$ & $\begin{array}{c}-0.104 \\
{[0.076]}\end{array}$ & $\begin{array}{c}-0.242 * * * \\
{[0.086]}\end{array}$ & $\begin{array}{c}0.018 \\
{[0.115]}\end{array}$ \\
\hline PPVT $>75 \%$ perc. & $\begin{array}{c}0.180 \\
{[0.117]}\end{array}$ & $\begin{array}{c}0.293 \\
{[0.238]}\end{array}$ & $\begin{array}{c}0.133 \\
{[0.165]}\end{array}$ & $\begin{array}{c}0.102 \\
{[0.106]}\end{array}$ & $\begin{array}{c}0.201 \\
{[0.215]}\end{array}$ & $\begin{array}{c}0.054 \\
{[0.146]}\end{array}$ \\
\hline Number of siblings & $\begin{array}{c}-0.086 * \\
{[0.051]}\end{array}$ & $\begin{array}{c}-0.060 \\
{[0.067]}\end{array}$ & $\begin{array}{c}-0.110 \\
{[0.068]}\end{array}$ & $\begin{array}{c}-0.058 \\
{[0.048]}\end{array}$ & $\begin{array}{c}-0.065 \\
{[0.067]}\end{array}$ & $\begin{array}{c}-0.052 \\
{[0.066]}\end{array}$ \\
\hline Birth order & $\begin{array}{c}-0.057 \\
{[0.058]}\end{array}$ & $\begin{array}{c}-0.065 \\
{[0.091]}\end{array}$ & $\begin{array}{c}-0.031 \\
{[0.079]}\end{array}$ & $\begin{array}{c}-0.043 \\
{[0.057]}\end{array}$ & $\begin{array}{c}-0.075 \\
{[0.087]}\end{array}$ & $\begin{array}{c}-0.010 \\
{[0.081]}\end{array}$ \\
\hline Log of birth weight & $\begin{array}{c}0.144 \\
{[0.173]}\end{array}$ & $\begin{array}{c}0.106 \\
{[0.213]}\end{array}$ & $\begin{array}{c}0.071 \\
{[0.262]}\end{array}$ & $\begin{array}{c}0.123 \\
{[0.175]}\end{array}$ & $\begin{array}{c}0.214 \\
{[0.244]}\end{array}$ & $\begin{array}{c}0.126 \\
{[0.254]}\end{array}$ \\
\hline Extraversion & $\begin{array}{c}-0.001 \\
{[0.038]}\end{array}$ & $\begin{array}{c}0.027 \\
{[0.043]}\end{array}$ & $\begin{array}{c}-0.057 \\
{[0.061]}\end{array}$ & & & \\
\hline Conscientiousness & $\begin{array}{c}-0.081 * * \\
{[0.033]}\end{array}$ & $\begin{array}{c}-0.045 \\
{[0.044]}\end{array}$ & $\begin{array}{c}-0.144^{* * *} \\
{[0.051]}\end{array}$ & & & \\
\hline Agreeableness & $\begin{array}{c}-0.012 \\
{[0.038]}\end{array}$ & $\begin{array}{c}-0.007 \\
{[0.046]}\end{array}$ & $\begin{array}{c}-0.011 \\
{[0.058]}\end{array}$ & & & \\
\hline Openness & $\begin{array}{c}-0.058 * \\
{[0.035]}\end{array}$ & $\begin{array}{c}0.000 \\
{[0.050]}\end{array}$ & $\begin{array}{c}-0.087^{*} \\
{[0.051]}\end{array}$ & & & \\
\hline Neuroticism & $\begin{array}{c}0.004 \\
{[0.038]}\end{array}$ & $\begin{array}{c}-0.039 \\
{[0.039]}\end{array}$ & $\begin{array}{c}0.075 \\
{[0.065]}\end{array}$ & & & \\
\hline
\end{tabular}


Table 4: ... continued

\begin{tabular}{|c|c|c|c|c|c|c|}
\hline Problems with peers & $\begin{array}{c}0.054 \\
{[0.034]}\end{array}$ & $\begin{array}{l}0.130 * * \\
{[0.056]}\end{array}$ & $\begin{array}{c}0.005 \\
{[0.051]}\end{array}$ & & & \\
\hline Prosocial behavior & $\begin{array}{c}0.036 \\
{[0.041]}\end{array}$ & $\begin{array}{c}0.013 \\
{[0.050]}\end{array}$ & $\begin{array}{c}0.089 \\
{[0.065]}\end{array}$ & & & \\
\hline Empathy & $\begin{array}{l}0.117 * * \\
{[0.056]}\end{array}$ & $\begin{array}{c}0.032 \\
{[0.072]}\end{array}$ & $\begin{array}{l}0.188^{* *} \\
{[0.081]}\end{array}$ & & & \\
\hline Prosociality mother & & & & $\begin{array}{c}0.102 \\
{[0.087]}\end{array}$ & $\begin{array}{c}0.133 * * \\
{[0.056]}\end{array}$ & $\begin{array}{c}0.013 \\
{[0.178]}\end{array}$ \\
\hline Costly prosociality mother & & & & $\begin{array}{c}0.026 \\
{[0.087]}\end{array}$ & $\begin{array}{c}-0.030 \\
{[0.115]}\end{array}$ & $\begin{array}{c}0.138 \\
{[0.119]}\end{array}$ \\
\hline Envy mother & & & & $\begin{array}{c}-0.029 \\
{[0.108]}\end{array}$ & $\begin{array}{c}0.002 \\
{[0.121]}\end{array}$ & $\begin{array}{c}0.031 \\
{[0.158]}\end{array}$ \\
\hline Costly envy mother & & & & $\begin{array}{c}-0.034 \\
{[0.100]}\end{array}$ & $\begin{array}{c}-0.146 \\
{[0.154]}\end{array}$ & $\begin{array}{l}-0.007 \\
{[0.149]}\end{array}$ \\
\hline Other person present & $\begin{array}{c}0.064 \\
{[0.063]} \\
\end{array}$ & $\begin{array}{l}0.110^{*} \\
{[0.064]}\end{array}$ & $\begin{array}{c}0.007 \\
{[0.097]} \\
\end{array}$ & $\begin{array}{c}0.059 \\
{[0.065]}\end{array}$ & $\begin{array}{l}0.119 * \\
{[0.071]}\end{array}$ & $\begin{array}{c}0.021 \\
{[0.100]}\end{array}$ \\
\hline $\begin{array}{l}\text { Observations } \\
\text { Pseudo } R^{2}\end{array}$ & $\begin{array}{c}211 \\
0.209\end{array}$ & $\begin{array}{c}100 \\
0.341\end{array}$ & $\begin{array}{c}111 \\
0.277\end{array}$ & $\begin{array}{c}212 \\
0.149\end{array}$ & $\begin{array}{c}100 \\
0.280\end{array}$ & $\begin{array}{c}112 \\
0.136\end{array}$ \\
\hline
\end{tabular}

Notes: The table reports the marginal effects of probit models (standard errors in parentheses). The dependent variable is a dummy variable indicating whether the child has chosen the costly envy option. Significance levels are denoted as follows: ${ }^{*} \mathrm{p}<0.1,{ }^{* *} \mathrm{p}<0.05,{ }^{* * *} \mathrm{p}<0.01$. Additional controls: age in months, age in months squared, mother's vocational training (dummy), mother college degree (dummy), Log of monthly household income. Source: SOEP Berlin Pilot Study, own calculations. 
Table 5: Regression results across all games: Weakly spiteful

\begin{tabular}{|c|c|c|c|c|c|c|}
\hline & Full Sample & $\begin{array}{c}\text { Female } \\
\text { (1) }\end{array}$ & Male & Full Sample & $\begin{array}{c}\text { Female } \\
\text { (2) }\end{array}$ & Male \\
\hline Female & $\begin{array}{c}-0.077 \\
{[0.059]}\end{array}$ & & & $\begin{array}{c}-0.072 \\
{[0.059]}\end{array}$ & & \\
\hline CFT1>50\% perc. & $\begin{array}{c}0.210 * * * \\
{[0.066]}\end{array}$ & $\begin{array}{c}0.125 \\
{[0.093]}\end{array}$ & $\begin{array}{c}0.305^{* * *} \\
{[0.101]}\end{array}$ & $\begin{array}{c}0.162 * * \\
{[0.068]}\end{array}$ & $\begin{array}{c}0.063 \\
{[0.098]}\end{array}$ & $\begin{array}{c}0.219 * * \\
{[0.095]}\end{array}$ \\
\hline CFT1>75\% perc. & $\begin{array}{c}0.075 \\
{[0.092]}\end{array}$ & $\begin{array}{c}0.116 \\
{[0.149]}\end{array}$ & $\begin{array}{c}0.150 \\
{[0.154]}\end{array}$ & $\begin{array}{c}0.082 \\
{[0.092]}\end{array}$ & $\begin{array}{c}0.126 \\
{[0.140]}\end{array}$ & $\begin{array}{c}0.089 \\
{[0.142]}\end{array}$ \\
\hline PPVT>50\% perc. & $\begin{array}{c}-0.013 \\
{[0.071]}\end{array}$ & $\begin{array}{c}-0.208 * * \\
{[0.091]}\end{array}$ & $\begin{array}{c}0.173 \\
{[0.107]}\end{array}$ & $\begin{array}{c}-0.013 \\
{[0.072]}\end{array}$ & $\begin{array}{c}-0.207^{* *} \\
{[0.083]}\end{array}$ & $\begin{array}{c}0.163 \\
{[0.106]}\end{array}$ \\
\hline PPVT $>75 \%$ perc. & $\begin{array}{c}0.116 \\
{[0.104]}\end{array}$ & $\begin{array}{c}0.160 \\
{[0.203]}\end{array}$ & $\begin{array}{c}0.073 \\
{[0.137]}\end{array}$ & $\begin{array}{c}0.051 \\
{[0.092]}\end{array}$ & $\begin{array}{c}0.123 \\
{[0.189]}\end{array}$ & $\begin{array}{c}0.015 \\
{[0.126]}\end{array}$ \\
\hline Number of siblings & $\begin{array}{c}-0.040 \\
{[0.045]}\end{array}$ & $\begin{array}{c}-0.033 \\
{[0.060]}\end{array}$ & $\begin{array}{c}-0.031 \\
{[0.058]}\end{array}$ & $\begin{array}{c}-0.025 \\
{[0.044]}\end{array}$ & $\begin{array}{c}-0.041 \\
{[0.064]}\end{array}$ & $\begin{array}{c}-0.010 \\
{[0.057]}\end{array}$ \\
\hline Birth order & $\begin{array}{c}-0.090 * \\
{[0.054]}\end{array}$ & $\begin{array}{c}-0.091 \\
{[0.084]}\end{array}$ & $\begin{array}{c}-0.101 \\
{[0.072]}\end{array}$ & $\begin{array}{c}-0.072 \\
{[0.054]}\end{array}$ & $\begin{array}{c}-0.098 \\
{[0.083]}\end{array}$ & $\begin{array}{c}-0.054 \\
{[0.075]}\end{array}$ \\
\hline Log of birth weight & $\begin{array}{c}0.181 \\
{[0.159]}\end{array}$ & $\begin{array}{c}0.128 \\
{[0.192]}\end{array}$ & $\begin{array}{c}0.079 \\
{[0.231]}\end{array}$ & $\begin{array}{c}0.153 \\
{[0.161]}\end{array}$ & $\begin{array}{c}0.298 \\
{[0.233]}\end{array}$ & $\begin{array}{c}0.136 \\
{[0.231]}\end{array}$ \\
\hline Extraversion & $\begin{array}{c}0.016 \\
{[0.035]}\end{array}$ & $\begin{array}{c}0.023 \\
{[0.039]}\end{array}$ & $\begin{array}{c}-0.016 \\
{[0.054]}\end{array}$ & & & \\
\hline Conscientiousness & $\begin{array}{c}-0.045 \\
{[0.031]}\end{array}$ & $\begin{array}{c}-0.049 \\
{[0.039]}\end{array}$ & $\begin{array}{c}-0.070 \\
{[0.044]}\end{array}$ & & & \\
\hline Agreeableness & $\begin{array}{c}-0.015 \\
{[0.036]}\end{array}$ & $\begin{array}{c}-0.020 \\
{[0.043]}\end{array}$ & $\begin{array}{c}-0.025 \\
{[0.052]}\end{array}$ & & & \\
\hline Openness & $\begin{array}{c}-0.071^{* *} \\
{[0.031]}\end{array}$ & $\begin{array}{c}0.012 \\
{[0.045]}\end{array}$ & $\begin{array}{c}-0.116 * * \\
{[0.046]}\end{array}$ & & & \\
\hline Neuroticism & $\begin{array}{c}-0.007 \\
{[0.035]}\end{array}$ & $\begin{array}{c}-0.050 \\
{[0.036]}\end{array}$ & $\begin{array}{c}0.057 \\
{[0.056]}\end{array}$ & & & \\
\hline
\end{tabular}


Table 5: ... continued

\begin{tabular}{|c|c|c|c|c|c|c|}
\hline Problems with peers & $\begin{array}{c}0.046 \\
{[0.031]}\end{array}$ & $\begin{array}{l}0.101^{* *} \\
{[0.050]}\end{array}$ & $\begin{array}{c}-0.003 \\
{[0.044]}\end{array}$ & & & \\
\hline Prosocial behavior & $\begin{array}{c}0.020 \\
{[0.038]}\end{array}$ & $\begin{array}{c}0.018 \\
{[0.044]}\end{array}$ & $\begin{array}{c}0.049 \\
{[0.057]}\end{array}$ & & & \\
\hline Empathy & $\begin{array}{c}0.083 \\
{[0.052]}\end{array}$ & $\begin{array}{c}0.010 \\
{[0.065]}\end{array}$ & $\begin{array}{l}0.140^{*} \\
{[0.072]}\end{array}$ & & & \\
\hline Prosociality mother $^{\mathrm{A}}$ & & & & $\begin{array}{c}0.170^{* * *} \\
{[0.058]}\end{array}$ & $\begin{array}{c}0.117 * * \\
{[0.056]}\end{array}$ & \\
\hline Costly prosociality mother & & & & $\begin{array}{c}0.009 \\
{[0.084]}\end{array}$ & $\begin{array}{l}-0.089 \\
{[0.130]}\end{array}$ & $\begin{array}{l}0.151 * \\
{[0.091]}\end{array}$ \\
\hline Envy mother & & & & $\begin{array}{c}-0.010 \\
{[0.104]}\end{array}$ & $\begin{array}{c}0.010 \\
{[0.114]}\end{array}$ & $\begin{array}{c}0.032 \\
{[0.149]}\end{array}$ \\
\hline Costly envy mother & & & & $\begin{array}{c}-0.032 \\
{[0.099]}\end{array}$ & $\begin{array}{l}-0.079 \\
{[0.135]}\end{array}$ & $\begin{array}{l}-0.001 \\
{[0.141]}\end{array}$ \\
\hline Other person present & $\begin{array}{c}0.038 \\
{[0.060]}\end{array}$ & $\begin{array}{c}0.065 \\
{[0.061]}\end{array}$ & $\begin{array}{c}-0.037 \\
{[0.089]}\end{array}$ & $\begin{array}{c}0.034 \\
{[0.061]}\end{array}$ & $\begin{array}{c}0.075 \\
{[0.073]}\end{array}$ & $\begin{array}{c}0.004 \\
{[0.091]}\end{array}$ \\
\hline $\begin{array}{l}\text { Observations } \\
\text { Pseudo } R^{2}\end{array}$ & $\begin{array}{c}211 \\
0.205\end{array}$ & $\begin{array}{c}100 \\
0.330\end{array}$ & $\begin{array}{c}111 \\
0.318\end{array}$ & $\begin{array}{c}212 \\
0.167\end{array}$ & $\begin{array}{c}100 \\
0.255\end{array}$ & $\begin{array}{c}112 \\
0.200\end{array}$ \\
\hline
\end{tabular}

Notes: The table reports the marginal effects of probit models (standard errors in parentheses). The dependent variable is a dummy variable indicating whether the child is classified as weakly spiteful. Significance levels are denoted as follows: ${ }^{*} \mathrm{p}<0.1,{ }^{* *} \mathrm{p}<0.05, * * * \mathrm{p}<0.01$. Additional controls: age in months, age in months squared, mother's vocational training (dummy), mother college degree (dummy), Log of monthly household income. A: Mother’s prosociality was not included in the males’ sample because not being proscocial predicts the outcome perfectly. Source: SOEP Berlin Pilot Study, own calculations. 
Table 6: Regression results across all games: Strongly spiteful

\begin{tabular}{|c|c|c|c|c|c|c|}
\hline & Full Sample & $\begin{array}{c}\text { Female } \\
(1)\end{array}$ & Male & Full Sample & $\begin{array}{c}\text { Female } \\
\text { (2) }\end{array}$ & Male \\
\hline Female & $\begin{array}{c}-0.016 \\
{[0.040]}\end{array}$ & & & $\begin{array}{c}-0.048 \\
{[0.045]}\end{array}$ & & \\
\hline CFT1>50\% perc. & $\begin{array}{c}0.176^{* * * *} \\
{[0.052]}\end{array}$ & $\begin{array}{c}0.122 \\
{[0.078]}\end{array}$ & $\begin{array}{c}0.250 * * \\
{[0.098]}\end{array}$ & $\begin{array}{c}0.172 * * * \\
{[0.054]}\end{array}$ & $\begin{array}{l}0.133^{*} \\
{[0.080]}\end{array}$ & $\begin{array}{c}0.226 * * * \\
{[0.076]}\end{array}$ \\
\hline CFT1>75\% perc. & $\begin{array}{c}-0.030 \\
{[0.041]}\end{array}$ & $\begin{array}{c}-0.040 \\
{[0.044]}\end{array}$ & $\begin{array}{c}-0.002 \\
{[0.030]}\end{array}$ & $\begin{array}{c}-0.029 \\
{[0.050]}\end{array}$ & $\begin{array}{l}-0.042 \\
{[0.053]}\end{array}$ & $\begin{array}{l}-0.035 \\
{[0.066]}\end{array}$ \\
\hline PPVT $>50 \%$ perc. & $\begin{array}{c}-0.028 \\
{[0.047]}\end{array}$ & $\begin{array}{c}-0.039 \\
{[0.057]}\end{array}$ & $\begin{array}{c}-0.007 \\
{[0.030]}\end{array}$ & $\begin{array}{c}-0.007 \\
{[0.054]}\end{array}$ & $\begin{array}{c}-0.038 \\
{[0.061]}\end{array}$ & $\begin{array}{c}0.050 \\
{[0.080]}\end{array}$ \\
\hline PPVT>75\% perc. & $\begin{array}{c}0.075 \\
{[0.079]}\end{array}$ & $\begin{array}{c}-0.023 \\
{[0.065]}\end{array}$ & $\begin{array}{c}0.051 \\
{[0.069]}\end{array}$ & $\begin{array}{c}0.003 \\
{[0.062]}\end{array}$ & $\begin{array}{l}-0.047 \\
{[0.057]}\end{array}$ & $\begin{array}{c}-0.004 \\
{[0.082]}\end{array}$ \\
\hline Number of siblings & $\begin{array}{c}-0.006 \\
{[0.030]}\end{array}$ & $\begin{array}{l}-0.010 \\
{[0.042]}\end{array}$ & $\begin{array}{c}-0.000 \\
{[0.016]}\end{array}$ & $\begin{array}{c}0.005 \\
{[0.033]}\end{array}$ & $\begin{array}{l}-0.020 \\
{[0.047]}\end{array}$ & $\begin{array}{c}0.015 \\
{[0.039]}\end{array}$ \\
\hline Birth order & $\begin{array}{c}-0.061 * \\
{[0.036]}\end{array}$ & $\begin{array}{c}-0.079 \\
{[0.062]}\end{array}$ & $\begin{array}{c}-0.021 \\
{[0.024]}\end{array}$ & $\begin{array}{c}-0.054 \\
{[0.040]}\end{array}$ & $\begin{array}{l}-0.098 \\
{[0.065]}\end{array}$ & $\begin{array}{c}-0.014 \\
{[0.047]}\end{array}$ \\
\hline Log of birth weight & $\begin{array}{c}0.167 \\
{[0.117]}\end{array}$ & $\begin{array}{c}0.074 \\
{[0.149]}\end{array}$ & $\begin{array}{c}0.071 \\
{[0.089]}\end{array}$ & $\begin{array}{c}0.181 \\
{[0.133]}\end{array}$ & $\begin{array}{c}0.200 \\
{[0.176]}\end{array}$ & $\begin{array}{c}0.231 \\
{[0.190]}\end{array}$ \\
\hline Extraversion & $\begin{array}{c}0.000 \\
{[0.023]}\end{array}$ & $\begin{array}{c}-0.009 \\
{[0.027]}\end{array}$ & $\begin{array}{c}-0.003 \\
{[0.014]}\end{array}$ & & & \\
\hline Conscientiousness & $\begin{array}{c}-0.034 \\
{[0.021]}\end{array}$ & $\begin{array}{c}-0.009 \\
{[0.029]}\end{array}$ & $\begin{array}{c}-0.024 \\
{[0.020]}\end{array}$ & & & \\
\hline Agreeableness & $\begin{array}{c}0.007 \\
{[0.024]}\end{array}$ & $\begin{array}{c}-0.006 \\
{[0.029]}\end{array}$ & $\begin{array}{c}0.002 \\
{[0.014]}\end{array}$ & & & \\
\hline Openness & $\begin{array}{c}-0.055 * * * \\
{[0.021]}\end{array}$ & $\begin{array}{c}0.005 \\
{[0.034]}\end{array}$ & $\begin{array}{c}-0.043 \\
{[0.030]}\end{array}$ & & & \\
\hline Neuroticism & $\begin{array}{c}-0.002 \\
{[0.024]}\end{array}$ & $\begin{array}{c}-0.010 \\
{[0.024]}\end{array}$ & $\begin{array}{c}0.003 \\
{[0.019]}\end{array}$ & & & \\
\hline
\end{tabular}


Table 6: ... continued

\begin{tabular}{|c|c|c|c|c|c|c|}
\hline Problems with peers & $\begin{array}{c}0.019 \\
{[0.021]}\end{array}$ & $\begin{array}{l}0.061^{*} \\
{[0.034]}\end{array}$ & $\begin{array}{c}-0.013 \\
{[0.014]}\end{array}$ & & & \\
\hline Prosocial behavior & $\begin{array}{c}-0.029 \\
{[0.025]}\end{array}$ & $\begin{array}{c}-0.004 \\
{[0.030]}\end{array}$ & $\begin{array}{l}-0.013 \\
{[0.019]}\end{array}$ & & & \\
\hline Empathy & $\begin{array}{l}0.077 * * \\
{[0.036]}\end{array}$ & $\begin{array}{c}-0.004 \\
{[0.046]}\end{array}$ & $\begin{array}{c}0.058 \\
{[0.047]}\end{array}$ & & & \\
\hline Costly prosociality mother & & & & $\begin{array}{c}0.035 \\
{[0.054]}\end{array}$ & $\begin{array}{l}-0.015 \\
{[0.082]}\end{array}$ & $\begin{array}{c}0.090 \\
{[0.055]}\end{array}$ \\
\hline Envy mother & & & & $\begin{array}{c}-0.050 \\
{[0.089]}\end{array}$ & $\begin{array}{c}-0.054 \\
{[0.115]}\end{array}$ & $\begin{array}{l}-0.006 \\
{[0.119]}\end{array}$ \\
\hline Costly envy mother & & & & $\begin{array}{c}0.046 \\
{[0.059]}\end{array}$ & $\begin{array}{c}0.048 \\
{[0.058]}\end{array}$ & $\begin{array}{c}0.036 \\
{[0.090]}\end{array}$ \\
\hline Other person present & $\begin{array}{c}0.023 \\
{[0.039]}\end{array}$ & $\begin{array}{c}-0.002 \\
{[0.050]}\end{array}$ & $\begin{array}{c}-0.003 \\
{[0.025]}\end{array}$ & $\begin{array}{c}0.016 \\
{[0.046]}\end{array}$ & $\begin{array}{c}0.006 \\
{[0.061]}\end{array}$ & $\begin{array}{c}0.006 \\
{[0.062]}\end{array}$ \\
\hline $\begin{array}{l}\text { Observations } \\
\text { Pseudo } R^{2}\end{array}$ & $\begin{array}{c}211 \\
0.250\end{array}$ & $\begin{array}{c}100 \\
0.266\end{array}$ & $\begin{array}{c}111 \\
0.456\end{array}$ & $\begin{array}{c}212 \\
0.169\end{array}$ & $\begin{array}{c}100 \\
0.190\end{array}$ & $\begin{array}{c}112 \\
0.244\end{array}$ \\
\hline
\end{tabular}

Notes: The table reports the marginal effects of probit models (standard errors in parentheses). The dependent variable is a dummy variable indicating whether the child is classified as strongly spiteful. Significance levels are denoted as follows: ${ }^{*} \mathrm{p}<0.1,{ }^{* *} \mathrm{p}<0.05,{ }^{* * *} \mathrm{p}<0.01$. Additional controls: age in months, age in months squared, mother's vocational training (dummy), mother college degree (dummy), Log of monthly household income. In models (2) mother's prosociality was not included in the males' sample because not being proscocial predicts the outcome perfectly. Source: SOEP Berlin Pilot Study, own calculations. 